\title{
Plant Biomass Production in Constructed Wetlands Treating Swine Wastewater in Tropical Climates
}

\author{
Mayerlin Sandoval-Herazo ${ }^{1,2}$, Georgina Martínez-Reséndiz ${ }^{1}$, Eduardo Fernández Echeverria ${ }^{3}$, \\ Gregorio Fernández-Lambert $1, *$ (i) and Luis Carlos Sandoval Herazo ${ }^{4, *}$ (D)
}

1 Division of Graduate Studies and Research, Tecnológico Nacional de México/Instituto Tecnológico Superior de Misantla, Km 1.8 Carretera a Loma del Cojolite, Misantla, Veracruz 93821, Mexico; mayerli.sandoval24@gmail.com (M.S.-H.); georgina.martinez.tecm@gmail.com (G.M.-R.)

2 Department of Business Management Engineering, Tecnológico Nacional de México/Instituto Tecnológico de Misantla, Veracruz, Km 1.8 Carretera a Loma del Cojolite, Misantla, Veracruz 93821, Mexico

3 Industrial Engineering Department, Tecnológico Nacional de México/ITS de Zacapoaxtla, Carretera Acuaco-Zacapoaxtla Km. 8, Col. Totoltepec, Zacapoaxtla 73680, Mexico; iiefernandez@otmail.com

4 Wetlands and Environmental Sustainability Laboratory, Division of Graduate Studies and Research, Tecnológico Nacional de México/Instituto Tecnológico de Misantla, Veracruz, Km 1.8 Carretera a Loma del Cojolite, Misantla, Veracruz 93821, Mexico

* Correspondence: gfernandezl@itsm.edu.mx (G.F.-L.); lcsandovalh@gmail.com (L.C.S.H.); Tel.: +52-2-351-031-175 (G.F.-L.); +52-2-351-115-306 (L.C.S.H.)

Citation: Sandoval-Herazo, M.; Martínez-Reséndiz, G.; Fernández Echeverria, E.; Fernández-Lambert, G.; Sandoval Herazo, L.C. Plant Biomass Production in Constructed Wetlands Treating Swine Wastewater in Tropical Climates. Fermentation 2021, 7, 296. https://doi.org/ $10.3390 /$ fermentation7040296

Academic Editors: Eldon R. Rene,

Maria Carmen Veiga and

Christian Kennes

Received: 2 November 2021

Accepted: 29 November 2021

Published: 2 December 2021

Publisher's Note: MDPI stays neutral with regard to jurisdictional claims in published maps and institutional affiliations.

Copyright: (c) 2021 by the authors. Licensee MDPI, Basel, Switzerland. This article is an open access article distributed under the terms and conditions of the Creative Commons Attribution (CC BY) license (https:// creativecommons.org/licenses/by/ $4.0 /)$.

\begin{abstract}
The production of both aboveground and belowground plant biomass in constructed wetlands $(\mathrm{CW})$ is a poorly understood topic, although vegetation plays an important role in the process of pollutant removal from wastewater. The objective of this study was to evaluate the aboveground and belowground biomass production of Typha latifolia and Canna hybrids in a largescale constructed wetland treating swine wastewater in tropical climates. Parameters, such as temperature, DO, pH, COD, TSS, TN, TP, and TC, as well as destructive and non-destructive biomass, were evaluated. It was found that, despite the high concentrations of pollutants, the vegetation adapted easily and also grew healthily despite being exposed to high concentrations of pollutants from swine water. Although Typha latifolia (426 plants) produced fewer plants than Canna hybrids (582 plants), the higher biomass of the Typha latifolia species was slightly higher than that of Canna hybrids by $5 \%$. On the other hand, the proximity of the water inlet to the system decreased the capacity for the development of a greater number of seedlings. As for the elimination of pollutants, after treatment in the constructed wetland, COD: $83.6 \pm 16.9 \%$; TSS: $82.2 \pm 17.7 \%$; TN: $94.4 \pm 15.8 \%$; TP: $82.4 \pm 23.2 \%$; and TC: $94.4 \pm 4.4 \%$ were significantly reduced. These results show that wetlands constructed as tertiary systems for the treatment of swine wastewater produce a large amount of plant biomass that significantly helps to reduce the concentrations of pollutants present in this type of water in tropical areas. The use of these plants is recommended in future wetland designs to treat swine wastewater.
\end{abstract}

Keywords: constructed wetlands; plant biomass; swine wastewater treatment

\section{Introduction}

Constructed wetlands (CWs) are eco-treatment technologies that have gained popularity due to their low cost, easy operation, and zero energy costs in solving water pollution problems of domestic, industrial, and agricultural origin [1,2]. Their components and performance are well known and widely studied $[3,4]$, including hydraulic retention times [5-7], substrates ranging from petrified materials to recyclable waste [8]. On the other hand, vegetation is one of the components of CWs that plays a very important role in the system [9], since it has three main functions: the first is that it absorbs pollutants and favors their elimination [10], the second is that it provides oxygen through the release in the radical zone [11], and the third is hydraulic, which is intensified in CWs with horizontal 
subsurface flow [12-14]. These functions are affected or favored in the selection of plants. Some of the best-known vegetation used in subsurface flow CWs systems are Cyperus papyrus, Phragmites australis, Typha latifolia, and Scirpus spp. [15], which are typical plants of natural wetlands [16]. Ornamental plants are also used in CWs, the most common are Canna spp., Iris spp., Heliconia spp., and Zantedeschia spp., [17]. Even when plants that can be used in CWs are known, their functioning and pollutant removal capacity of these plants are under discussion, authors such as Kim et al. [18] indicate that plants (macrophytes) in CWs absorb less than $5 \%$ of total phosphorus present in wastewater. In addition, the removal of nitrogen present in wastewater by plants is 5 to $10 \%$, which can translated into a range of 15 to $32 \mathrm{mg} \mathrm{N} \mathrm{g}^{-1}$ [19]. Other studies have reported on plant development and biomass production in horizontal flow CWs, such as [20], which found a positive correlation between aboveground biomass production with $\mathrm{PO}_{4}-\mathrm{P}$ removal of Typha spp., plants, Zantedeschia aethiopica, and Alpinia purpurata, finding that Typha spp., had higher aboveground biomass development than belowground. In systems with biomass (common reed) in relation to systems without the presence of biomass, with continuous feeding, the mass quantity of ammonium removed ranged from 0.52 to 0.58 and $0.67 \mathrm{~g} \mathrm{~N} \mathrm{~m}^{-2}$, removing $26 \%$ more than systems without the presence of biomass, but the production of biomass was not quantified [21].

These data are encouraging in terms of nutrient removal in horizontal flow CWs with constant saturation, even though these have been evaluated with domestic or municipal wastewater, without taking into account waters with a higher presence of nutrients that can increase its toxicity, decreasing biomass production, and the nutrient assimilation capacity of plants in CWs under continuous saturation conditions [22]. However, to this date there are very few studies that quantify the biomass production of vegetation both in the root zone and in the aerial zone in horizontal subsurface flow CWs [23-25] and much less when wastewater of agro-industrial origin is used, as is the case of wastewater generated by the swine agroindustry that has already been evaluated in CWs at laboratory or mesocosm scale in terms of its removal of pollutants [26,27]. Therefore, this study reports for the first time the total biomass production of both above and belowground biomass from a large-scale horizontal subsurface flow constructed wetland in the vegetation of a system that treats water as a tertiary swine wastewater treatment system on a farm located in a tropical region.

\section{Materials and Methods}

\subsection{Biomass Source}

In this study, 5 randomly selected plants of Typha latifolia and Canna hybrids were evaluated (for each large-scale constructed wetland zone A, B, C, D, as shown in Figure 1), respectively, from a constructed wetland $(\mathrm{CW})$ of horizontal flow $20 \mathrm{~m}$ long $\times 5 \mathrm{~m}$ wide with a depth of $0.65 \mathrm{~m}$ (Figure 1), filled with red volcanic gravel, commonly used in Mexico as a filter in constructed wetlands [28], with diameter $2-4 \mathrm{~cm}$, with a porosity of $0.68 \%$, in which a total of 600 plants were planted. The first $10 \mathrm{~m}$ of the system were planted with Typha latifolia ( 300 plants of $15 \mathrm{~cm}$ in height) and the remaining $10 \mathrm{~m}$ closer to the $\mathrm{CW}$ outlet were planted with Canna hybrids ( 300 plants of $10 \mathrm{~cm}$ in height), which were obtained in their natural state in the central zone of the state of Veracruz, Mexico. The system was installed in a 5000-pig farm where the CW (tertiary treatment) was part of a treatment train that treated the wastewater produced by pig farming on the farm, which produced $3 \mathrm{~m}^{3}$ of wastewater per day. The full-scale CW operated with a hydraulic retention time of 14 days. All systems operated under real environmental conditions in a warm subhumid climate with an average annual temperature of $23^{\circ} \mathrm{C}$, an average annual precipitation of $1500 \mathrm{~mm}$ and at $500 \mathrm{~m}$ above sea level [29]. 


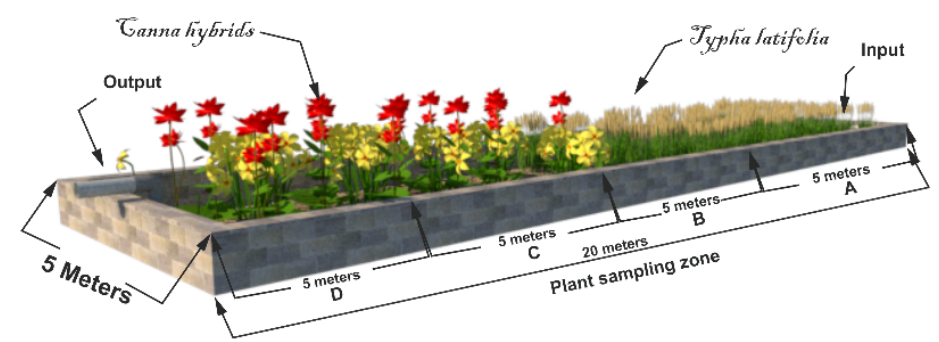

Figure 1. Large-scale constructed wetland system.

The plants were planted in four different zones (Figure 1), Typha latifolia., was exposed to greater toxicity since it would be planted at the beginning of the treatment in a constructed wetland with horizontal flow, in these systems, since as the wastewater advances in the system it tends to decrease the concentrations of contamination.

\subsection{Operation and Duration of Monitoring}

The system received pre-treated water from a treatment train consisting of one anaerobic reactor and one aerobic reactor, with a capacity of $72 \mathrm{~m}^{3}$ and a hydraulic retention time of 14 days reactively.

The system was evaluated for a period of 6 months. Before starting the evaluation period, the system was adapted to the new water quality conditions for 3 months; the plants were induced to an initial preparation process where they were acclimatized to the current water quality conditions. It is worth mentioning that the plants were taken from a natural wetland that receives untreated domestic wastewater, which facilitated their adaptation to the new water pollution conditions.

As for contaminant removal (CR), it was determined by Equation (1):

$$
\mathrm{Em}=((\mathrm{Ci}-\mathrm{Ce}) / \mathrm{Ci}) \times 100 \%
$$

where $\mathrm{Ci}$ is the concentration of the pollutant in the influent $\left(\mathrm{mg} \mathrm{L}^{-1}\right)$ and $\mathrm{Ce}$ is the concentration of the pollutant in the effluent $\left(\mathrm{mg} \mathrm{L}^{-1}\right)$.

\subsection{Survival to Adaptation and Survival of Plants}

Plant survival was monitored visually every month, all plants were numbered to have control of their survival and the offspring were assigned a new numbering month by month, to give adequate follow-up to their plant development, as well as flower production. As a control, the same parameters were measured in 5 plants of the same age of maturity planted in soil in their natural state, planted in the same initial characteristics of size as those of $\mathrm{CW}$, and the same monitoring time was used.

\subsection{Measurement of Plant Development}

Plant development was measured in the sixth month using a tape measure, recording $100 \%$ of the mature and new individuals of each plant species, in order to measure height, leaf length, number of leaves, leaf width, and these data were processed to obtain averages and establish future non-destructive biomass volumes. As a control, the same parameters were measured in 5 plants of the same age of maturity planted in soil in their natural state with the same characteristics as those of the initial CW in terms of size and monitoring time.

\subsection{Destructive Biomass Measurement}

Five mature plants of Typha latifolia and Canna hybrids, respectively, were sacrificed, in which the area and below-ground biomass were determined by separating the plant from the root and washing it with tap water to remove the presence of solids in the root that could interfere with the biomass result. They were immediately placed in an oven at $100{ }^{\circ} \mathrm{C}$ for $72 \mathrm{~h}$, in order to have a constant weight and be able to calculate the biomass [30]. The plants were weighed on a high-precision digital analytical balance (Shi-madzu AUW-220D, 
SHIMADZU, Berlin, German). Subsequently, the results of both above and below ground were summed, the results of the five individuals of each plant species were averaged in order to calculate the ratio of $1 \mathrm{~g}$ above and below ground biomass to plant size. In the case of Canna hybrids, the plan growth formula was used to obtain the data in Table 1 for growth in both plant species. As a control, the same parameters were measured in 5 plants of the same maturity age planted in soil in their natural state, planted in the same characteristics of the initial CW in terms of size and monitoring time.

Table 1. Characteristics of wastewater that entered the $\mathrm{CW}$ tertiary treatment system.

\begin{tabular}{lccc}
\hline Parameter & $\begin{array}{c}\text { Input } \\
\left(\mathbf{m g ~ L}^{-1}\right)\end{array}$ & $\begin{array}{c}\text { Output } \\
\left(\mathbf{m g ~ L}^{-\mathbf{1}}\right)\end{array}$ & Method \\
\hline Water temperature $\left({ }^{\circ} \mathrm{C}\right)$ & $16.4 \pm 4.2$ & $15.2 \pm 2.5$ & \\
Dissolved Oxygen (DO) & $1.7 \pm 0.3$ & $2.4 \pm 0.2$ & \\
pH & $7.1 \pm 0.2$ & $7.8 \pm 0.3$ & \\
Chemical Oxygen Demand (COD) & $789.6 \pm 134.1$ & $129.8 \pm 53.6$ & Standard \\
Total Suspended Solids (TSS) & $607.3 \pm 107.5$ & $108 \pm 94.5$ & Method [31] \\
Total Nitrogen (TN) & $294.3 \pm 46.6$ & $16.4 \pm 9.1$ & \\
Total Phosphorus (TP) & $53.4 \pm 12.4$ & $9.4 \pm 4.6$ & \\
Total Coliforms (TC) & $1.6 \times 10^{0} \pm 0.7$ & $9 \times 10^{-1} \pm 0.6$ & \\
\hline
\end{tabular}

Average \pm standard error $(n=24)$.

\subsection{Non-Destructive Biomass Calculation. Non-Destructive Biomass Measurements}

For the calculation of the total non-destructive biomass of the CW system in all plants, the total number of plants with an average age of 6 months was considered and the total number of new seedlings was weighted by means of multivariate statistical analysis where the data of $1 \mathrm{~g}$ of biomass of the root zone and $1 \mathrm{~g}$ of biomass of the area zone (including stems and root) were obtained, data from the quantification of destructive biomass.

Finally, by the ratio of dry weight and height of the plants, the total extrapolated biomass produced both above and below ground was calculated for each of the two species planted in CW.

\subsection{Quantification of Total Coliforms}

The quantification of fecal coliforms was performed using the Colilert method. This methodology allows the detection of water quality sanitation indicators based on the ability of total coliforms to produce the enzyme $\beta$-galactosidase that metabolizes the Colilert indicator nutrient, O-nitrophenyl- $\beta$-Dgalactopyranoside (ONPG), which changes the samples to a yellow color. The Colilert method is endorsed by the US Environmental Protection Agency (EPA) for use in water and wastewater analysis, guaranteeing its efficiency [31].

\subsection{Data Analysis}

The statistical analysis and calculation of the data was carried out in the SPSS V18.0 program (IBM, Armonk, NY, USA). Analysis of variance (ANOVA) was used to determine the differences in the growth of plants in $\mathrm{CW}$ and in their natural state, a Pearson correlation test with a $95 \%$ confidence interval was used, as well as a test of independence of data.

\section{Results and Discussion}

\subsection{Monitoring Operation and Duration}

The swine wastewater that entered the wetlands presented two pretreatments; Table 1 shows the characteristics of the system's input and output.

\subsection{Water Quality Parameters}

\subsubsection{Temperature, $\mathrm{pH}$, Dissolved Oxygen}

Water temperature is an indicator that directly affects both the development of microorganisms and the presence of dissolved oxygen (DO) in constructed wetlands, and 
the optimum temperature in these systems for the correct development of biochemical reactions is $16-35^{\circ} \mathrm{C}[32,33]$. The average inlet and outlet temperature is shown in Table 1 , with a non-significant decrease. Points out that low temperatures are associated with a decrease in organic matter $(\mathrm{OM})$ removal, i.e., temperature promotes $\mathrm{OM}$ oxidation [34]. On the other hand, $\mathrm{pH}$ is a variable that like temperature has an effect on the development of organisms, the suitable range for the existence of most life is 5-9 [35]. For this parameter, an increase of 7 units was observed in the output with respect to the input of the system evaluated, which is in agreement with the range indicated by Sandoval-Herazo et al. [35].

\subsubsection{Physicochemical Parameters and Microorganisms}

COD determines the amount of oxygen required to oxidize the organic matter in a water sample. In this study, there was a clear significant difference $(p=0.05)$ between the output and the input (Table 1). Suspended solids are substances present in water that have a solid state when they are pure, when determining this parameter, a significant decrease $(p<0.05)$ was observed between the output $\left(108.0 \pm 94.5 \mathrm{mg} \mathrm{L}^{-1}\right)$ and the input $\left(607.3 \pm 3.0 \mathrm{mg} \mathrm{L}^{-1}\right)$. Total nitrogen is the TN of all forms present in this case, in the water samples obtained, which in this work presented a significant decrease $(p<0.05)$ in the output $\left(16.4 \pm 9.1 \mathrm{mg} \mathrm{L}^{-1}\right)$ with respect to the input $\left(294.3 \pm 46.6 \mathrm{mg} \mathrm{L}^{-1}\right)$. Wetlands perform the removal processes of this nutrient by adhesion, absorption, sedimentation, and microbiological processes [36]. Phosphorus (P) is another major pollutant in swine effluents, $\mathrm{P}$ in swine wastewater occurs in the form of organic and inorganic P. P removal in wetlands is achieved by chemical and physical adsorption, precipitation with other ions, sedimentation, and uptake by plants and microorganisms. Inorganic $\mathrm{P}$ is adsorbed to the substrate matrix or becomes available for uptake by plants and microorganisms [37]. In this study the TP concentration was $9.4 \pm 4.6 \mathrm{mg} \mathrm{L}^{-1}$ at the end of treatment. The presence of TC in treated wastewater indicates poor quality treatment; in this study, the presence of TC at the entrance of the treatment was $1.6 \times 10^{0} \pm 0.7$ and at the exit of $9 \times 10^{-1} \pm 0.6$, showing a decrease in its presence.

\subsubsection{Removal of Contaminants}

Figure 2 describes the percentage of removal in 5 parameters evaluated in the system studied, the first of which is the concentration of organic matter, expressed as COD, whose evaluation presents a mean removal value of $83.6 \pm 16.9 \%$, higher than that $(79.4 \%)$ using Typha latifolia, [38]. An $89.1 \%$ removal rate using the same organism was obtained in the treatment of basic pollutants in wastewater [39], similar to that obtained in this work.

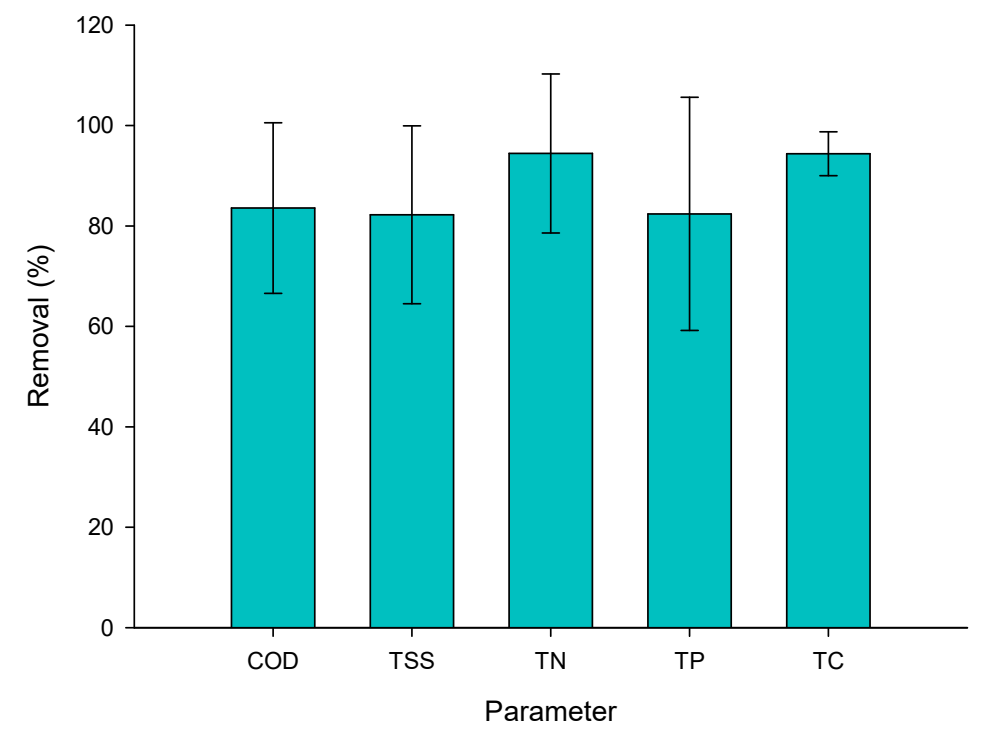

Figure 2. Removal of contaminants. 
TSS is the residue remaining in a capsule after evaporating and drying a sample at a temperature of $105.0 \pm 2.0^{\circ} \mathrm{C}$. TSS removal by the CW system averaged $82.2 \pm 17.7 \%$.

The main inorganic nutrients entering wetlands are nitrogen and phosphorus. In the wetland, nitrogen and phosphorus are removed from the surface water and transferred to the sediment, wetland plants or atmosphere in this study, total Nitrogen was removed $94.4 \pm 15.8 \%$ and total Phosphorus was removed $82.40 \pm 23.2 \%$. Among the different nitrogen species, they greatly influence aquatic systems as they are readily available to be taken up by aquatic microorganisms instead of other organic particles [40].

Phosphorus is removed primarily through physical and chemical processes, entering a wetland in both organic and inorganic forms. The relative proportion of each form depends on the soil characteristics, vegetation, and land use of the drainage basin Phosphorus assimilation and storage in plants depends on vegetative type and growth characteristics. Leaves and stems of emergent and submerged vegetation help settle particles by slowing water and allowing the particles to fall [41].

To continuously remove phosphorus, it is necessary to "build" new soils within the wetland from remnant plant stems, leaves, root debris, and non-decomposable parts of algae, bacteria, fungi, and dead invertebrates [42].

CW have been shown to be capable of removing a wide variety of pollutants, including bacterial contamination [43]. In this study this is no exception since the removal of TC was $94.4 \pm 4.4 \%$, indicative of efficient treatment. Giácoman-Vallejos et al. [44] conducted a study where he evaluated the removal of pathogens from domestic and swine wastewater using experimental constructed wetlands, he found that Typha latifolia $(86 \%)$ is more efficient in removing TC than Typha dominguensis.

They developed and evaluated of a horizontal underground flow CWs on a pilot scale for the treatment of swine wastewater, using a Pennisetum clandestinum and Pennisetum purpureum, As a result, they reported a removal efficiency for the vegetation used of 64.9 and $66.5 \%$ for COD, 58.9 and $62.5 \%$ for TN, and up to $48.53 \%$ for TP [45]. With these results they concluded that the use of horizontal flow wetlands is feasible, as they can efficiently treat swine effluents, since it is possible to remove organic matter and nutrients.

It should be noted that retention time defines the length of time that contaminants remain in contact with plants and microorganisms to be biologically and chemically transformed [46].

During the development of this work, it was observed that Canna hybrids presented a greater adaptation to the environment in which they developed, since during the 6 months of evaluation there were 0 non-viable (lifeless) individuals, while the adaptation of Typha latifolia at the beginning of the experiment did not occur, since during the first and third month of the development of the experiment 128 and 43 individuals, respectively, ceased to be viable. This means that Canna hybrids adapt more easily to changes (Table 2), in addition to having a higher rate of new individuals $(n=581)$, which is an advantage, since the greater the number of live individuals, the higher the water quality at the exit of the treatment.

Table 2. Adaptation and survival of species used.

\begin{tabular}{|c|c|c|c|c|c|c|c|c|}
\hline & \multirow{2}{*}{ Species } & \multicolumn{6}{|c|}{ Number of Plants per Month } & \multirow{2}{*}{$\begin{array}{c}\text { Average Plant Height (m) at the End } \\
\text { of the Study (Month 6) }\end{array}$} \\
\hline & & 1 & 2 & 3 & 4 & 5 & 6 & \\
\hline \multirow{4}{*}{$\begin{array}{l}\text { Typha } \\
\text { latifolia }\end{array}$} & Initial & 300 & 172 & 257 & 253 & 305 & 379 & 1.72 \\
\hline & Dead & 128 & 0 & 43 & 0 & 0 & 0 & \\
\hline & New & 0 & 85 & 39 & 52 & 74 & 47 & 0.74 \\
\hline & $\begin{array}{l}\text { Sown in natural } \\
\text { environment }\end{array}$ & - & - & - & - & - & - & 1.56 \\
\hline \multirow{4}{*}{$\begin{array}{l}\text { Canna } \\
\text { hybrids }\end{array}$} & Initial & 300 & 274 & 274 & 386 & 481 & 521 & 1.61 \\
\hline & Dead & 26 & 0 & 0 & 0 & 0 & 0 & \\
\hline & New & 0 & 0 & 112 & 95 & 40 & 61 & 0.54 \\
\hline & $\begin{array}{l}\text { Sown in natural } \\
\text { environment }\end{array}$ & - & - & - & - & - & - & 0.97 \\
\hline
\end{tabular}




\subsection{Biomass}

The accumulation and distribution of biomass in plants are genotypic characteristics easily affected by the environment and its interaction [47]. Thus, the proportion of biomass assigned to leaves, stems and fruits at each developmental stage depends on growth rate and distribution rate, which are governed by leaf area, climate, and nutrient availability [48]. Figure 3 shows the growth rate of the species used. Figure 4 shows that the number of leaves of Canna hybrids was higher at the end of the experiment (17 leaves) compared to Typha latifolia (8 leaves). The stem thickness of Typha latifolia was greater from the beginning $(3.5 \mathrm{~cm})$ to the end $(6 \mathrm{~cm})$ of the experiment (Figure $4 \mathrm{~b}$ ).

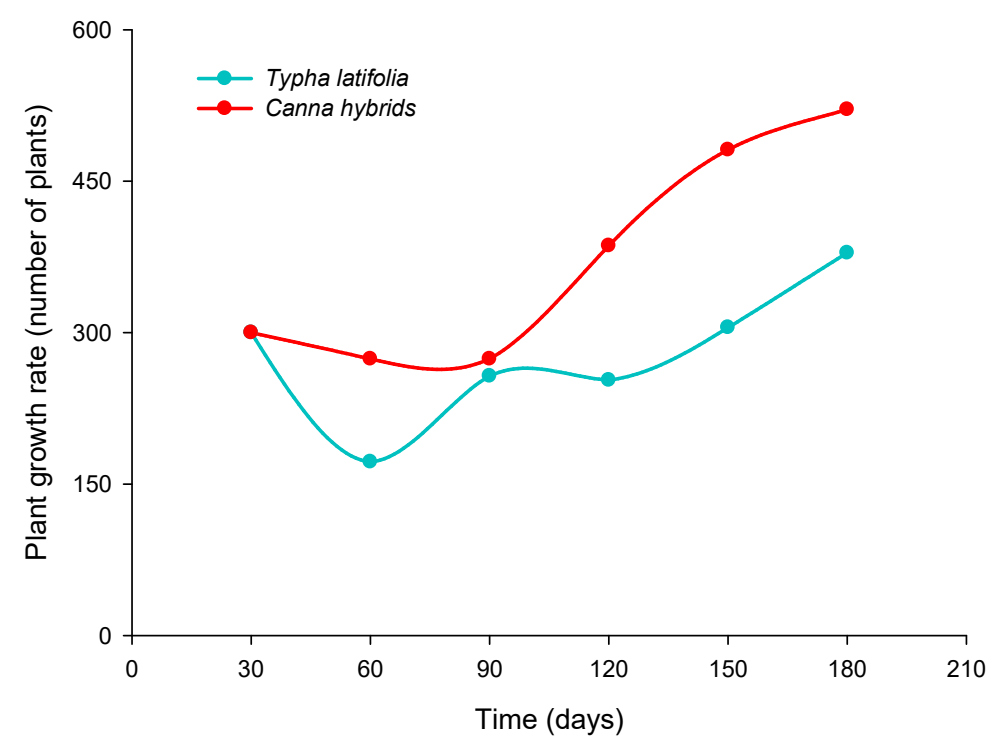

Figure 3. Plant growth in constructed wetlands.

The width of the leaves of Canna hybrids (Figure 4c) was greater than those of Typha latifolia, and conversely the length was greater in Typha latifolia (Figure 4c). The height of Typha latifolia was greater than that of Canna hybrids, in a study Typha latifolia significantly outperformed Juncus and Scirpus in both growth and effluent quality improvement [49], as shown in this work, the promised height of Typha latifolia was $1.72 \mathrm{~m}$, which means that Typha latifolia is a useful organism for plant biomass production and water quality improvement in a constructed wetland.

In a constructed wetland, the presence of biomass is important, since it represents a better removal of pollutants, even though found that in the treatment of lightly loaded wastewater, plants have a greater significant effect on purification than in normal water. This suggests that harvesting could be a valid exploitation strategy in dilute water conditions, but it is also important to evaluate when it should be carried out [50]. Wetland biomass is commonly used as livestock fodder, soil conditioner, or fertilizer due to its nutrient content, but could also be harvested for bioenergy production [51]. In ornamental plants, biomass increase does not represent a problem, since pruning can be performed continuously and the plants can be marketed.

The importance of fresh weight analysis (non-destructive biomass) in crops is that it includes the quantitative determination of the water content present. On the other hand, the evaluation of dry weight biomass (destructive biomass) represents the weight without water content. 


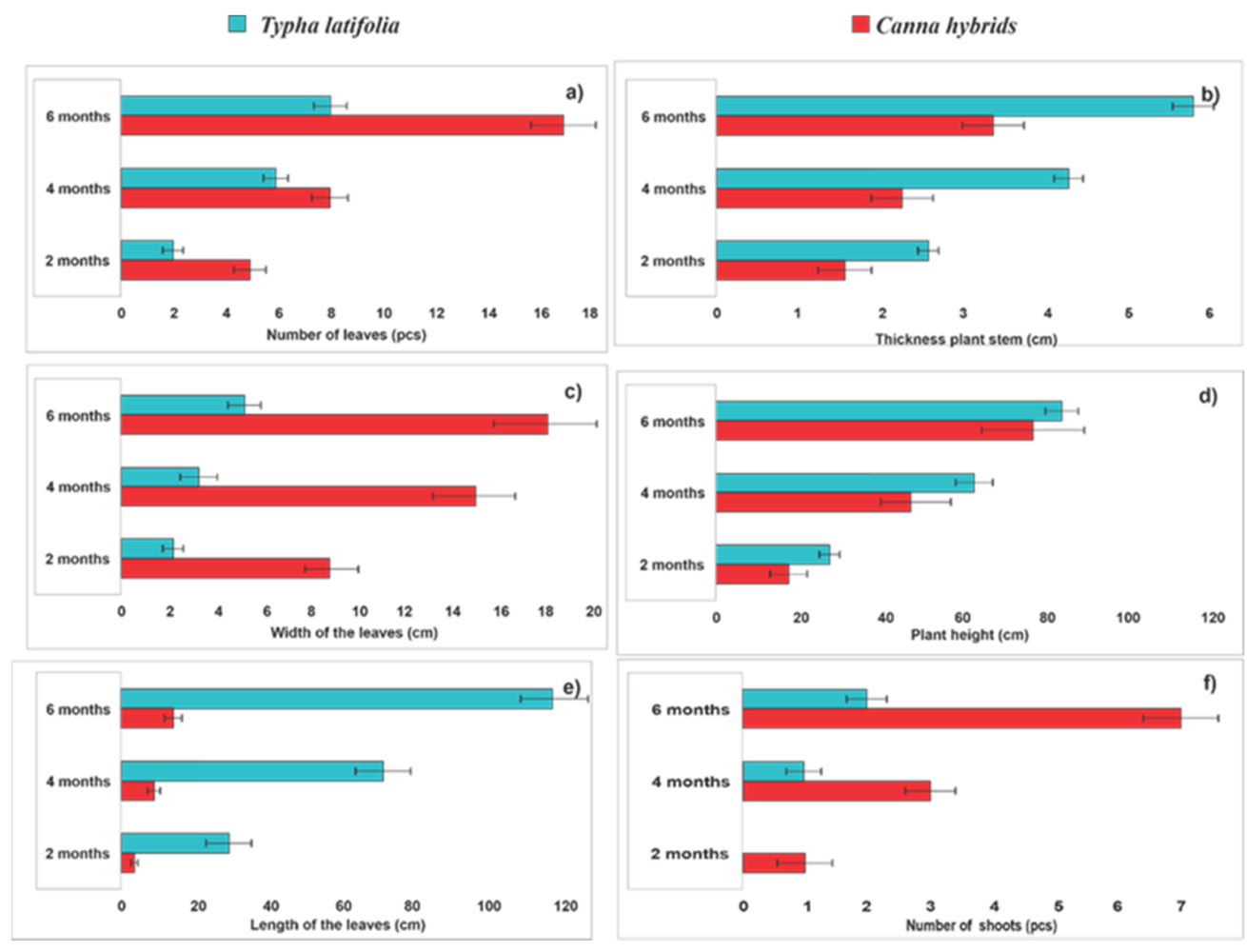

Figure 4. Typha latifolia and Canna hybrids development during the study period at the actual level. (a) Number of leaves, (b) Plant stem thickness, (c) Leaf width, (d) Plant height, (e) Leaf length, (f) Number of shoots. Mean \pm standard deviation.

\subsubsection{Destructive Biomass}

Figure 5 shows that there is a decrease from $A$ to $D$ in the dry weight of the plants evaluated in both leaves and roots. The Canna Hybrids at the entrance of the system developed less biomass (D). For Typha latifolia, a higher dry weight was obtained both in the aerial part and in the root $(\mathrm{A}, \mathrm{B})$. On the other hand, Canna Hybrids presented the lowest weight $(p<0.5)$ in the aerial part and in the root part, regarding Typha latifolia.

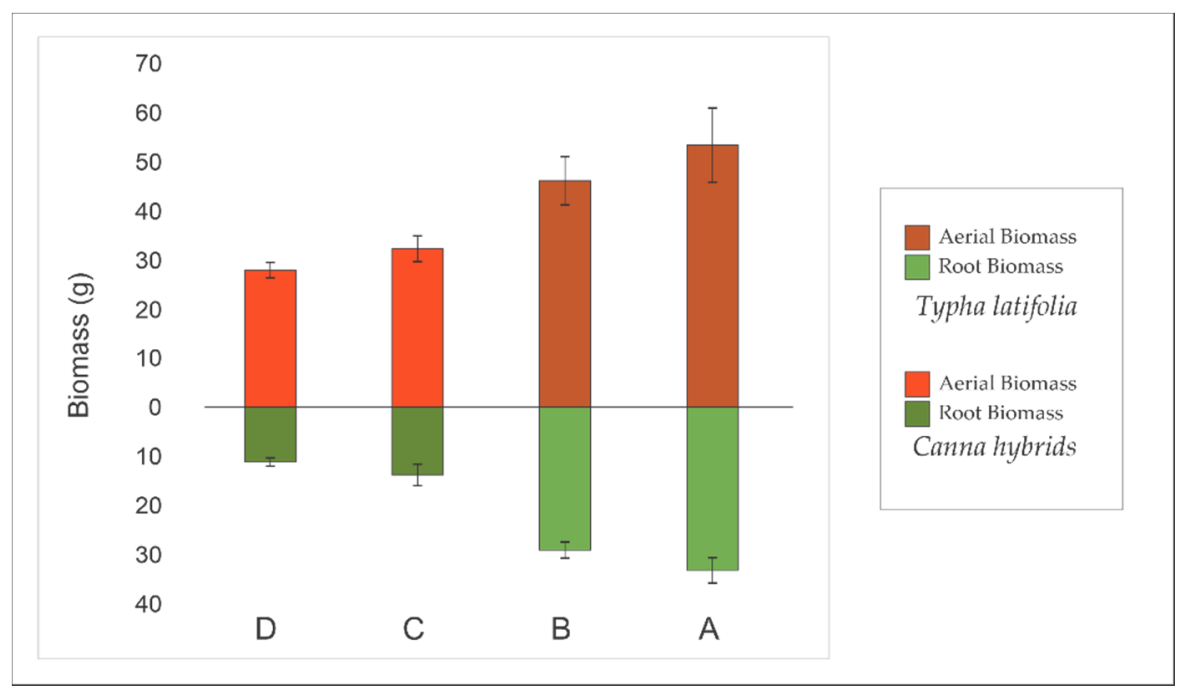

Figure 5. Aerial and root biomass development of Typha latifolia (zone A and B) and Canna hybrids (Zone C and D) of Constructed wetland as a tertiary swine wastewater treatment system. Mean \pm standard deviation. 


\subsubsection{Non-Destructive Biomass}

Table 3 shows the results of the non-destructive biomass analysis (root and leaf). The highest value obtained was for Typha latifolia in leaf $(20,238.60 \mathrm{~g})$ and root $(12,582.80 \mathrm{~g})$, which was located in position B of the system (see Figure 1) very close to the inlet, where the highest load of pollutants is found, therefore its development may be due to the fact that the nutritional load it received was used by the plant, through its large number of roots translocating the nutrients contained in the effluent to the aerial part. The fact that it had an extensive development promotes the efficiency of the system since the plants act as filters that remove, reduce, transform, mineralize, degrade, volatilize, concentrate, or stabilize pollutants (organic and inorganic) in soil, sludge, water, and sediments [52].

Table 3. Total biomass.

\begin{tabular}{cccc}
\hline Plant & & Zone & Total Biomass $\mathbf{( g )}$ \\
\hline & & Aerial & $16,585.80$ \\
Typha latifolia & R & Root & $10,482.80$ \\
& & Aerial & $20,238.60$ \\
& B & Root & $12,582.80$ \\
& & Aerial & $14,588.00$ \\
Canna hybrids & C & Root & 5835.20 \\
& & Aerial & $18,500.40$ \\
& D & Root & 7879.80 \\
\hline & & Total & $106,693.40$ \\
\hline
\end{tabular}

The second highest value was for plants located in position $\mathrm{D}$ (at the end of the system), the leaves had a weight of $18,500.40 \mathrm{~g}$ and the root had a weight of $7879.80 \mathrm{~g}$. Roots play an important role since they can only absorb nutrients if they are dissolved in water, so the plants that were arranged in A and C, probably received available (dissolved) nutrients. In total, 106,693.40 g of biomass were obtained in the system.

It would be of interest to perform an experiment where the placement of the plants is inverted to evaluate the same parameters and to know the influence of the nutrient load in the system.

At least biomass production in zone A and B of the Typha latifolia., it could be due to the highest levels of toxicity in which this plant was found exposed to being closer to the water inlet to the system.

\section{Conclusions}

This study demonstrated the adaptability and tolerance to high concentrations of contaminants of Typha latifolia and Canna hybrids plants, which although they have been widely used in constructed wetlands, very few studies have been evaluated in similar conditions, much less on a large scale, so their use is recommended in future designs that treat swine wastewater.

Regarding biomass production, more biomass was produced in the aerial zone in relation to the subterranean zone and more biomass was produced by Typha latifolia, in the constructed wetland zone "B" > " $\mathrm{A}$ " and in zone " $\mathrm{D}$ " > "C" of the Canna hybrids, the overall biomass production was greater in Typha latifolia, even though the Canna hybrids produced a greater number of seedlings. This may have been due to the fact that they were farther away from the entrance of water into the system where the presence of pollutants was still higher, a situation that favored their reproduction.

Typha latifolia is not adapting as well might be very well linked to the fact that the plant is struggling with toxic concentrations present in porcine wastewater and being in zones $\mathrm{A}$ and $\mathrm{B}$ of the $\mathrm{CW}$, closest to the inlet of water to the system.

As for the elimination of pollutants, after treatment in the constructed wetland, COD: $83.6 \pm 16.9 \%$; TSS: $82.2 \pm 17.7 \%$; TN: $94.4 \pm 15.8 \%$; TP: $82.4 \pm 23.2 \%$; and TC: $94.4 \pm 4.4 \%$ were significantly reduced. These results show that wetlands constructed as secondary 
systems for swine wastewater treatment produce a large amount of plant biomass that helps significantly to reduce the concentrations of pollutants present in this type of water in tropical areas, as it appears that the higher biomass production is related to a higher elimination of pollutants present in wastewater.

Author Contributions: Conceptualization, L.C.S.H., E.F.E. and G.F.-L.; methodology, L.C.S.H. and M.S.-H.; validation, L.C.S.H., M.S.-H. and G.M.-R.; formal analysis, L.C.S.H. and G.M.-R.; research, L.C.S.H., M.S.-H., G.M.-R. and G.F.-L.; resourcing, L.C.S.H. and G.F.-L.; data curation, L.C.S.H. and M.S.-H.; writing: preparation of original draft, L.C.S.H., E.F.E. and M.S.-H.; writing: review and editing, L.C.S.H. and E.F.E.; visualization, L.C.S.H., M.S.-H., G.M.-R. and G.F.-L.; supervision, L.C.S.H., G.M.-R., E.F.E. and M.S.-H.; project management, L.C.S.H.; funding acquisition, L.C.S.H., G.F.-L. and M.S.-H. All authors have read and agreed to the published version of the manuscript.

Funding: This study was funded by the Tecnológico Nacional de México in the Call 2019 "Support for Scientific and Technological Research". Project "Treatment of wastewater produced by swine microenterprises in Veracruz, Mexico by means of artificial wetlands (Code 503.19-P).

Informed Consent Statement: Not applicable.

Data Availability Statement: Not applicable.

Acknowledgments: Special thanks to the engineer Saul Antonio Rivera for his support in the realization of our graphs, and Melissa Galeana Luis, for the English revision of this study.

Conflicts of Interest: The authors declare no conflict of interest.

\section{References}

1. Garzón-Zuñiga, M.A.; Buelna, G. Caracterización de aguas residuales porcinas y su tratamiento por diferentes procesos en México. Rev. Int. Contam. Ambient. 2014, 30, 65-79. Available online: http://www.scielo.org.mx/scielo.php?script=sci_arttext\& pid=S0188-49992014000100006\&lng=es\&nrm=iso (accessed on 29 October 2021).

2. Parde, D.; Patwa, A.; Shukla, A.; Vijay, R.; Killedar, D.J.; Kumar, R. A review of constructed wetland on type, technology and treatment of wastewater. Environ. Technol. Innov. 2021, 21, 101261. [CrossRef]

3. Hammer, D.A. (Ed.) Constructed Wetlands for Wastewater Treatment: Municipal, Industrial and Agricultural; CRC Press: Boca Raton, FL, USA, 2020. Available online: https:/ / books.google.es / books?hl=es\&lr=\&id=wSAJEAAAQBAJ\&oi=fnd\&pg=PA1\&dq=2.\%0 9 Hammer,+D.+A.+(Ed.).+Constructed+wetlands+for+wastewater+treatment:+municipal,+industrial+and+agricultural.+2020. $+\mathrm{CRC}+$ Press.+\&ots=Oie5O_uWXw\&sig=nwK0uapCME5099K4KFJOBfU2vug\#v=onepage\&q\&f=false (accessed on 26 November 2021).

4. Kataki, S.; Chatterjee, S.; Vairale, M.G.; Dwivedi, S.K.; Gupta, D.K. Constructed wetland, an eco-technology for wastewater treatment: A review on types of wastewater treated and components of the technology (macrophyte, biolfilm and substrate). J. Environ. Manag. 2021, 283, 111986. [CrossRef] [PubMed]

5. Varma, M.; Gupta, A.K.; Ghosal, P.S.; Majumder, A. A review on performance of constructed wetlands in tropical and cold climate: Insights of mechanism, role of influencing factors, and system modification in low temperature. Sci. Total Environ. 2021, 755, 142540. [CrossRef]

6. Stephenson, R.; Sheridan, C. Review of experimental procedures and modelling techniques for flow behaviour and their relation to residence time in constructed wetlands. J. Water Process Eng. 2021, 41, 102044. [CrossRef]

7. Song, H.L.; Li, H.; Zhang, S.; Yang, Y.L.; Zhang, L.M.; Xu, H.; Yang, X.L. Fate of sulfadiazine and its corresponding resistance genes in up-flow microbial fuel cell coupled constructed wetlands: Effects of circuit operation mode and hydraulic retention time. Chem. Eng. J. 2018, 350, 920-929. [CrossRef]

8. Vera, I.; Verdejo, N.; Chávez, W.; Jorquera, C.; Olave, J. Influence of hydraulic retention time and plant species on performance of mesocosm subsurface constructed wetlands during municipal wastewater treatment in super-arid areas. J. Environ. Sci. Health Part A 2016, 51, 105-113. [CrossRef]

9. Yang, Y.; Zhao, Y.; Liu, R.; Morgan, D. Global development of various emerged substrates utilized in constructed wetlands. Bioresour. Technol. 2018, 261, 441-452. [CrossRef]

10. Shelef, O.; Golan-Goldhirsh, A.; Gendler, T.; Rachmilevitch, S. Physiological parameters of plants as indicators of water quality in a constructed wetland. Environ. Sci. Pollut. Res. 2011, 18, 1234-1242. [CrossRef] [PubMed]

11. Sánchez-Olivares, E.; Marín-Muñiz, J.L.; Hernández-Alarcón, M.E. Radial oxygen loss by roots of native tropical wetland plants of Veracruz in response of different flooding conditions. Bot. Sci. 2019, 97, 202-210. [CrossRef]

12. Pedescoll, A.; Uggetti, E.; Llorens, E.; Granés, F.; García, D.; García, J. Practical method based on saturated hydraulic conductivity used to assess clogging in subsurface flow constructed wetlands. Ecol. Eng. 2009, 35, 1216-1224. [CrossRef]

13. De Paoli, A.C.; Sperling, M.V. Evaluation of clogging in planted and unplanted horizontal subsurface flow constructed wetlands: Solids accumulation and hydraulic conductivity reduction. Water Sci. Technol. 2013, 67, 1345-1352. [CrossRef] 
14. Tang, P.; Yu, B.; Zhou, Y.; Zhang, Y.; Li, J. Clogging development and hydraulic performance of the horizontal subsurface flow stormwater constructed wetlands: A laboratory study. Environ. Sci. Pollut. Res. 2017, 24, 9210-9219. [CrossRef] [PubMed]

15. Vymazal, J. Plants used in constructed wetlands with horizontal subsurface flow: A review. Hydrobiologia 2011, 674, 133-156. [CrossRef]

16. Vymazal, J. Emergent plants used in free water surface constructed wetlands: A review. Ecol. Eng. 2013, 61, 582-592. [CrossRef]

17. Sandoval, L.; Zamora-Castro, S.A.; Vidal-Álvarez, M.; Marín-Muñiz, J.L. Role of wetland plants and use of ornamental flowering plants in constructed wetlands for wastewater treatment: A review. Appl. Sci. 2019, 9, 685. [CrossRef]

18. Kim, S.Y.; Geary, P.M. The impact of biomass harvesting on phosphorus uptake by wetland plants. Water Sci. Technol. 2001, 44, 61-67. [CrossRef]

19. Thable, T.S. Einbau und Abbau von Stickstoffverbindungen aus Abwasser in der Wurzelraumanlage Othfresen. Ph.D. Thesis, University of Kassel, Kassel, Germany, 1984.

20. Marín-Muñiz, J.L.; García-González, M.C.; Ruelas-Monjardín, L.C.; Moreno-Casasola, P. Influence of different porous media and ornamental vegetation on wastewater pollutant removal in vertical subsurface flow wetland microcosms. Environ. Eng. Sci. 2018, 35, 88-94. [CrossRef]

21. Caselles-Osorio, A.; García, J. Impact of different feeding strategies and plant presence on the performance of shallow horizontal subsurface-flow constructed wetlands. Sci. Total Environment. 2007, 378, 253-262. [CrossRef]

22. Stottmeister, U.; Wießner, A.; Kuschk, P.; Kappelmeyer, U.; Kästner, M.; Bederski, O.; Moormann, H. Effects of plants and microorganisms in constructed wetlands for wastewater treatment. Biotechnol. Adv. 2001, 22, 93-117. [CrossRef]

23. Wen, Y.; Chen, Y.; Zheng, N.; Yang, D.; Zhou, Q. Effects of plant biomass on nitrate removal and transformation of carbon sources in subsurface-flow constructed wetlands. Bioresour. Technol. 2010, 101, 7286-7292. [CrossRef]

24. Jia, L.; Wang, R.; Feng, L.; Zhou, X.; Lv, J.; Wu, H. Intensified nitrogen removal in intermittently-aerated vertical flow constructed wetlands with agricultural biomass: Effect of influent C/N ratios. Chem. Eng. J. 2018, 345, 22-30. [CrossRef]

25. Avellán, T.; Gremillion, P. Constructed wetlands for resource recovery in developing countries. Renew. Sustain. Energy Rev. 2019, 99, 42-57. [CrossRef]

26. Fia, F.R.L.; de Matos, A.T.; Fia, R.; de Matos, M.P.; Borges, A.C.; Baptestini, G.C.F. Kinetics and Removal Efficiency of Nitrogen in Constructed Wetlands Cultivated with Different Plant Species for Treating Swine Wastewater Applied at Different Rates. Water Air Soil Pollut. 2021, 232, 5-22. [CrossRef]

27. Feng, L.; He, S.; Wei, L.; Zhang, J.; Wu, H. Impacts of aeration and biochar on physiological characteristics of plants and microbial communities and metabolites in constructed wetland microcosms for treating swine wastewater. Environ. Res. 2021, 111415. [CrossRef] [PubMed]

28. Tejeda, A.; Barrera, A.; Zurita, F. Adsorption capacity of a volcanic rock-Used in constructedwetlands—For carbamazepine removal, and its modification with biofilm growth. Water 2017, 9, 721. [CrossRef]

29. INEGI. 2021. Available online: http://cuentame.inegi.org.mx/monografias/informacion/ver/territorio/clima.aspx?tema=me\& $\mathrm{e}=30$ (accessed on 28 October 2021).

30. Marín-Muñiz, J.L. Remoción de contaminantes de aguas residuales por medio de humedales artificiales establecidos en el municipio de Actopan, Veracruz, México. Rev. Mex. Ing. Química 2016, 15, 553-563. Available online: https://www.redalyc.org/ pdf/620/62046829021.pdf (accessed on 18 October 2021). [CrossRef]

31. APHA/AWWA/WEF. Standard Methods for the Examination of Water and Wastewater; American Public Health Association: Washington, DC, USA, 2005.

32. Akratos, C.S.; Tsihrintzis, V.A. Effect of temperature, HRT, vegetation and porous media on removal efficiency of pilot-scale horizontal subsurface flow constructed wetlands. Ecol. Eng. 2007, 29, 173-191. [CrossRef]

33. Sandoval-Herazo, M.; Nani, G.; Sandoval, L.; Rivera, S.; Fernández-Lambert, G.; Alvarado-Lassman, A. Evaluation of the performance of vertical partially saturated constructed wetlands for sewage treatment swine. Trop. Subtrop. Agroecosyst. 2020, 23. Available online: https:/ / www.revista.ccba.uady.mx/ojs/index.php/TSA/article/view/3138 (accessed on 21 October 2021).

34. Winthrop, A.C.; Hook, B.; Biederman, A.J.; Stein, R.O. Temperature and Wetland Plant Species Effects on Wastewater Treatment and Root Zone Oxidation. J. Environ. Qual. 2002, 31, 1010. [CrossRef]

35. Sandoval-Herazo, L.C.; Alvarado-Lassman, A.; Marín-Muñiz, J.L.; Méndez-Contreras, J.M.; Zamora-Castro, S.A. Effects of the use of ornamental plants and different substrates in the removal of wastewater pollutants through microcosms of constructed wetlands. Sustainability 2018, 10, 1594. [CrossRef]

36. Li, X.; Li, Y.; Li, Y.; Wu, J. Enhanced nitrogen removal and quantitative analysis of removal mechanism in multistage surface flow constructed wetlands for the large-scale treatment of swine wastewater. J. Environ. Manag. 2019, 15, 575-582. [CrossRef]

37. Reddy, G.B.; Forbes, D.A.; Hunt, P.G.; Cyrus, J.S. Effect of polyaluminium chloride on phosphorus removal in constructed wetlands treated with swine wastewater. Water Sci. Technol. 2011, 63, 2938-2943. [CrossRef] [PubMed]

38. Bedoya Pérez, J.C.; Ardila Arias, A.N.; Reyes Calle, J. Evaluation of a subsurface flow constructed wetland in treating wastewater generated at the University Institution College of Antioquia, Colombia. Rev. Int. Contam. Ambient. 2014, 30, $275-283$.

39. De la Cruz, N.; Esquius, L.; Grandjean, D.; Magnet, A.; Tungler, A.; De Alencastro, L.F.; Pulgarín, C. Degradación de contaminantes emergentes por $\mathrm{UV}, \mathrm{UV} / \mathrm{H}_{2} \mathrm{O}_{2}$ y foto-Fenton neutro a escala piloto en una planta de tratamiento de aguas residuales domésticas. Investig. Sobre Agua 2013, 47, 5836-5845. 
40. Yousaf, A.; Khalid, N.; Aqeel, M.; Noman, A.; Naeem, N.; Sarfraz, W.; Khalid, A. Nitrogen Dynamics in Wetland Systems and Its Impact on Biodiversity. Nitrogen 2021, 2, 13. [CrossRef]

41. Reddy, K.R.; Kadlec, R.H.; Flaig, E.; Gale, P.M. Phosphorus Retention in Streams and Wetlands: A Review. Crit. Rev. Environ. Sci. Technol. 1999, 29, 83-146. [CrossRef]

42. Spenser, E. Constructed Wetlands for Wastewater Treatment and Wildlife Habitat; United States Environmental Protection Agency: Washington, DC, USA, 1993.

43. Ottová, V.; Balcarová, J.; Vymazal, J. Microbial characteristics of constructed wetlands. Water Sci. Technol. 1997, 35, 117-123. [CrossRef]

44. Giácoman-Vallejos, G.; Ponce-Caballero, C.; Champagne, P. Pathogen removal from domestic and swine wastewater by experimental constructed wetlands. Water Sci. Technol. 2015, 71, 1263-1270. [CrossRef]

45. Udom, I.J.; Mbajiorgu, C.C.; Oboho, E.O. Development and evaluation of a constructed pilot-scale horizontal subsurface flow wetland treating piggery wastewater. Ain Shams Eng. J. 2018, 9, 3179-3185. [CrossRef]

46. Aslam, M.M.; Malik, M.; Baig, M.A.; Qazi, I.A.; Iqbal, J. Treatment performances of compost-based and gravel-based vertical flow wetlands operated identically for refinery wastewater treatment in Pakistan. Ecol. Eng. 2007, 30, 34-42. [CrossRef]

47. Rajwade, V.B.; Banafar, R.N.; Pathak, A.C. Growth analysis of potato in relation to biodinamic package and organic manures with chemical fertilizers. J. Indian Potato Assoc. 2000, 27, 55-58.

48. Barrientos Llanos, H.; Del Castillo Gutiérrez, C.R.; García Cárdenas, M. Análisis de crecimiento funcional, acumulación de biomasa y translocación de materia seca de ocho hortalizas cultivadas en invernadero. Rev. Investig. Innovación Agropecu. Recur. Nat. 2015, 2, 76-86. Available online: http://www.scielo.org.bo/scielo.php?pid=S2409-16182015000100010\&script=sci_arttext (accessed on 24 November 2021).

49. Coleman, J.; Hench, K.; Garbutt, K.; Sexstone, A.; Bissonnette, G.; Skousen, J. Treatment of domestic wastewater by three plant species in constructed wetlands. Water Air Soil Pollut. 2001, 128, 283-295. [CrossRef]

50. Soto, F.; García, M.; de Luís, E.; Bécares, E. Role of Scirpus lacustris in bacterial removal from wastewater. Water Sci. Technol. 1999, 40, 241-247. [CrossRef]

51. Licata, M.; Gennaro, M.C.; Tuttolomondo, T.; Leto, C.; La Bella, S. Investigación centrada en el rendimiento de las plantas en humedales artificiales y aplicación agronómica de aguas residuales tratadas: Un conjunto de estudios experimentales en Sicilia (Italia). PLoS ONE 2019, 14, 12. [CrossRef]

52. Delgadillo-López, A.E.; González-Ramírez, C.A.; Prieto-García, F.; Villagómez-Ibarra, J.R.; Acevedo-Sandoval, O. Fitorremediación: Una alternativa para eliminar la contaminación. Trop. Subtrop. Agroecosyst. 2011, 14, 597-612. 